\title{
Tide-induced microseismicity in the Mertz glacier grounding area, East Antarctica
}

\author{
Guilhem Barruol, ${ }^{1}$ Emmanuel Cordier, ${ }^{1}$ Jérôme Bascou, ${ }^{2}$ Fabrice R. Fontaine, ${ }^{1}$ \\ Benoit Legrésy, ${ }^{3}$ and Lydie Lescarmontier ${ }^{3,4}$ \\ Received 28 August 2013; revised 2 October 2013; accepted 2 October 2013; published 22 October 2013.
}

[1] The deployment of a seismic network along the Adélie and George $\mathrm{V}$ coasts in East Antarctica during the period 2009-2012 provides the opportunity to monitor cryoseismic activity and to obtain new insights on the relationship between tidal cycles and coastal glacier dynamics. Here we focus on records from a seismometer located on a rocky outcrop in the vicinity of the grounding line of the $35 \mathrm{~km}$ broad Mertz glacier, a major outflow of this region. We detect numerous icequakes $(50,000$ events within 10 months and up to 100 events/h) and demonstrate their clear tidal modulation. We suggest that they result from ice friction and fracturing around the rocky peak and from the glacier flexure in response to the falling and rising tides at its grounding area. We propose that such icequake monitoring could be used as a climate proxy since grounding lines are subject to migrate with sea level changes. Citation: Barruol, G., E. Cordier, J. Bascou, F. R. Fontaine, B. Legrésy, and L. Lescarmontier (2013), Tide-induced microseismicity in the Mertz glacier grounding area, East Antarctica, Geophys. Res. Lett., 40, 5412-5416, doi:10.1002/2013GL057814.

\section{Introduction}

[2] Coastal Antarctic and Greenland regions are subject to many kinds of cryoseismic events such as glacial earthquakes [e.g., Tsai and Ekstrom, 2007], iceberg collision [e.g., Talandier et al., 2006], glacier basal deformation [e.g., Anandakrishnan and Alley, 1997], and calving [O'Neel et al., 2007]. Here we focus the present study on the so-called "icequakes," events of small magnitude known to be induced by ice fracturing and crevasse opening [e.g., Neave and Savage, 1970; Sinadinovski et al., 1999]. Most of them are characterized by short-duration $(<5 \mathrm{~s})$ impulsive waveforms and by a 1-100 Hz frequency content [O'Neel et al., 2007]. Icequakes are of great interest since they occur as a result

Additional supporting information may be found in the online version of this article.

${ }^{1}$ Laboratoire GéoSciences Réunion, Université de La Réunion, Institut de Physique du Globe de Paris, Sorbonne Paris Cité, CNRS UMR 7154, Université Paris Diderot, Saint Denis, France.

${ }^{2}$ Université de Lyon, Université Jean Monnet, CNRS UMR 6524, Laboratoire Magmas et Volcans, Saint Etienne, France.

${ }^{3}$ Laboratoire d'Etude en Géophysique et Océanographie Spatiale, Toulouse, France.

${ }^{4}$ Research School of Earth Sciences, Australian National University, Acton, ACT, Australia.

Corresponding author: G. Barruol, Laboratoire GéoSciences Réunion, Université de La Réunion, Institut de Physique du Globe de Paris, Sorbonne Paris Cité, CNRS UMR 7154, Université Paris Diderot, FR-97744 Saint Denis, France. (guilhem.barruol@univ-reunion.fr)

(C)2013. American Geophysical Union. All Rights Reserved. 0094-8276/13/10.1002/2013GL057814 of the ice response to the local stress regime related to cryosphere dynamics and may reveal interaction with the ocean. Few experiments have demonstrated that tides may modulate glacier's motion [Bindschadler et al., 2003; Murray et al., 2007] and basal seismicity [Zoet et al., 2012], but to our knowledge, seismological observations of the tide modulation of surface icequakes are very rare [e.g., von der Osten-Woldenburg, 1990].

[3] The ArLiTA (Architecture de la Lithosphère de Terre Adélie) project comprises four broadband three-component seismic stations deployed in Adélie and George $\mathrm{V}$ lands (Figure 1a; see supporting information for instrument details). One of these stations was installed on Correll Nunatak $(\mathrm{CN})$, a rocky peak emerging from the surrounding Mertz glacier, at its grounding zone, i.e., at the transition between grounded to floating ice. The Mertz glacier, a major ice outflow of this region (Figure 1a), is characterized by a large floating ice tongue flowing at about $3 \mathrm{~m} / \mathrm{d}$ [Wendler et al., 1996] within a $35 \mathrm{~km}$ wide fjord into the open ocean. This tongue was up to $145 \mathrm{~km}$ long in 2009, $1200 \mathrm{~m}$ thick at its grounding line, gradually thinning to $300 \mathrm{~m}$ at its ocean end and broke in February 2010 to release a $80 \times 40 \mathrm{~km}$ large iceberg [Lescarmontier, 2012].

[4] The sinuous geometry of the Mertz grounding line, defined by double-difference interferometric synthetic aperture radar (InSAR) interferograms [Legresy et al., 2004] (Figure 1b) and the surface crevassing visible on the SPOT satellite image (Figure 1c), suggest that the nunatak interacts with the glacier's flow and induces large downstream ice fracturing. The interaction of the glacier with the bedrock topography, together with the tide-induced vertical and lateral displacement resulting in along- and acrossflow flexural deformations [Reeh et al., 2003; Vaughan, 1995], points to strain localization in this area through ice damage and crevassing that should have a cryoseismic signature. In order to monitor such microseismicity at the Mertz grounding line, we focus this study on the icequakes, ubiquitous within the raw seismic signals, particularly at station CN (Figure 2a).

\section{Results}

\subsection{Icequake Detection, Duration, and Magnitude}

[5] We performed an extensive detection of icequakes at the broadband stations by applying a short-term average/ long-term average algorithm [Lesage, 2009] (details are given in the supporting information). We found a clear spatial and temporal variability in the number of detected events. We observed about 700 events/month at PM and CP stations (Figure 1a), located at large distances $(>10 \mathrm{~km})$ to an active glacier with a developed floating ice tongue; higher values of 


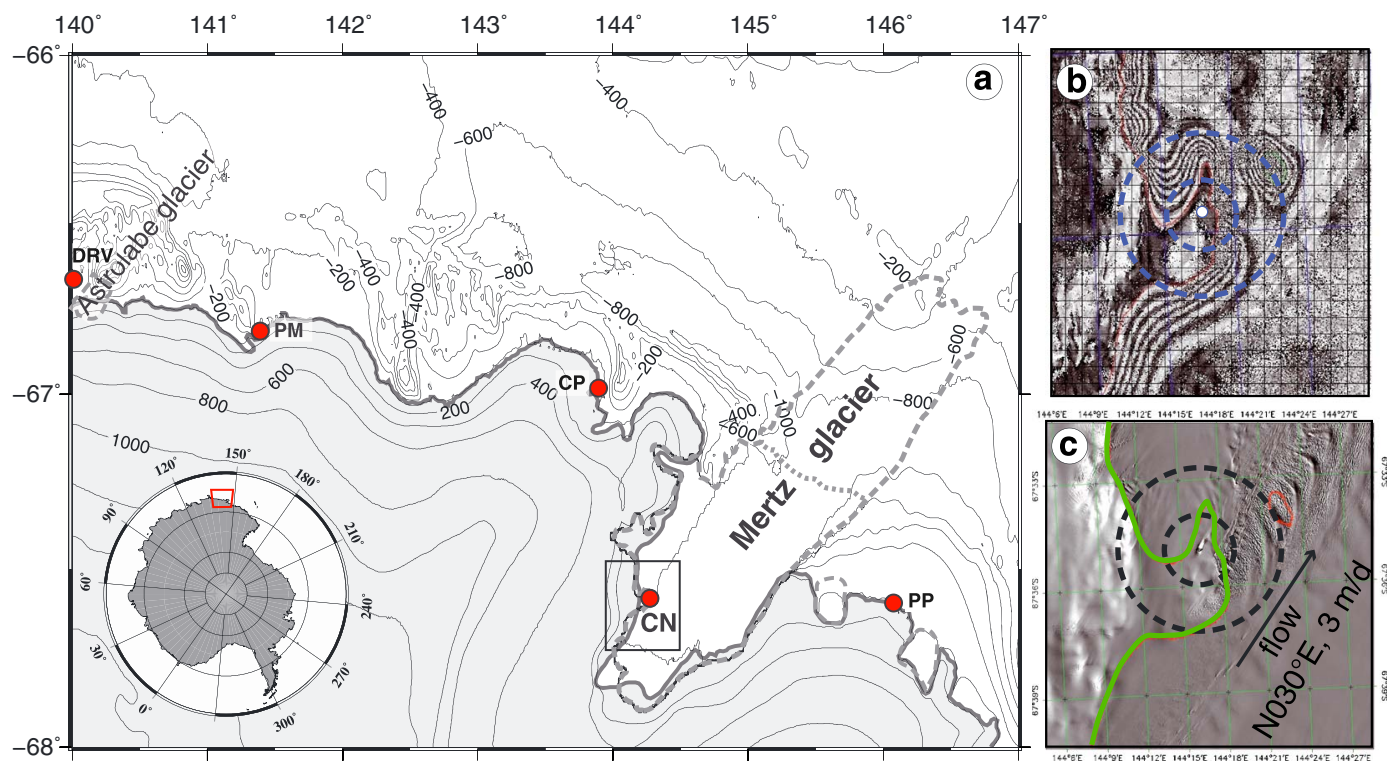

Figure 1. (a) Location of the seismic stations deployed during the period from November 2009 to November 2012 by the ArLITA project: $\mathrm{PM}=$ Port Martin, $\mathrm{CP}=$ Cape Pigeon, $\mathrm{CN}=$ Correll Nunatak, $\mathrm{PP}=$ Penguin Point, $\mathrm{DRV}=$ Dumont d'Urville GEOSCOPE station. Also reported on this map are the contours of the floating glaciers (dashed grey lines) and the line along which the February 2010 Mertz glacier calving occurred (dotted line). (b) Zoom of the InSAR double-difference interferogram [Legresy et al., 2004] around Correll Nunatak showing the complex geometry of the grounding line, together with $2 \mathrm{~km}$ and $5 \mathrm{~km}$ radius circles around CN. (c) Zoom on a SPOT satellite image around CN showing the surface crevassing downstream of the Correll Nunatak, together with the Mertz grounding line and the flow vector.

about 1500 events/month at DRV and PP stations, installed at 1 and $10 \mathrm{~km}$, respectively, to glaciers with developed floating ice tongues; and a large seismicity up to 5000 events/month at station $\mathrm{CN}$, located on the Mertz grounding zone.

[6] The detected icequakes are characterized by impulsive signals containing a wide frequency spectrum up to at least $20 \mathrm{~Hz}$ (the Nyquist frequency, since the data are sampled at $40 \mathrm{~Hz}$ ), as shown Figure 2b. These events do not show evidence of distinct $P$ and $S$ wave arrivals but are horizontally polarized along directions ranging from $\mathrm{N} 90^{\circ} \mathrm{E}$ to $\mathrm{N} 150^{\circ} \mathrm{E}$. This suggests that they are generated by ice fracturing and crevassing processes [e.g., Neave and Savage, 1970] occurring east to southeast of $\mathrm{CN}$. The event duration (Figure 2c) is dominated by a single class of events, with a maximum occurrence at $0.5 \mathrm{~s}$.

[7] Assuming that icequakes are governed by similar laws as earthquakes, which seems to be the case from Amery ice shelf seismicity analysis [Bassis et al., 2007], we estimate their magnitudes by using an empirical relationship linking the event duration $d$ and the magnitude $M_{d}$, such as $M_{d} \approx-0.9+2 \log (d)$ [Lee et al., 1972]. At station CN, most durations are smaller than $2.0 \mathrm{~s}$ and indicate mostly negative magnitudes and likely small epicentral distances.

[8] The frequency-duration distribution of icequakes at $\mathrm{CN}$ does not follow a Gaussian-like distribution but better fits a Gutenberg-Richter distribution [Gutenberg and Richter,
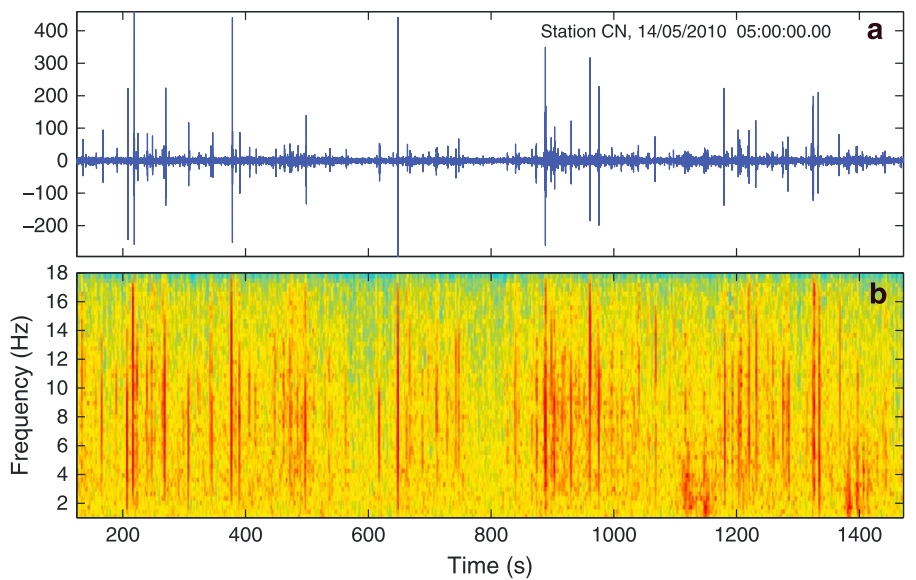

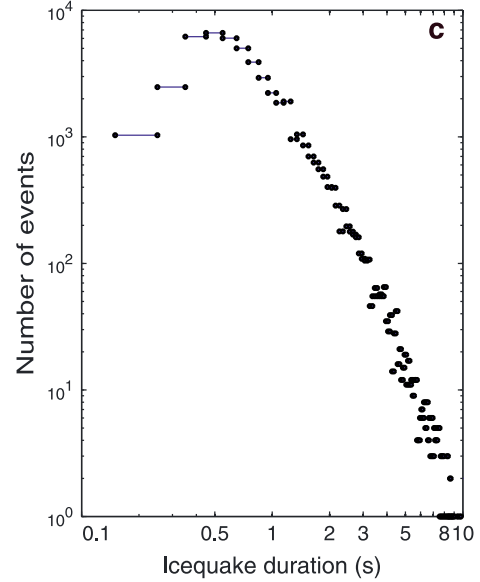

Figure 2. (a) Example of the signal recorded at station CN. Twenty-five minutes of seismicity on 14 May 2010, starting at 05:00:00, vertical seismogram, band-pass filtered between 1 and $18 \mathrm{~Hz}$ showing the numerous impulsive icequakes. (b) Timefrequency plot of the above seismogram showing the short duration and the broad frequency content of the icequakes. (c) Distribution of the duration of the 48,959 icequakes detected at $\mathrm{CN}$ for the 10 month recording period. 

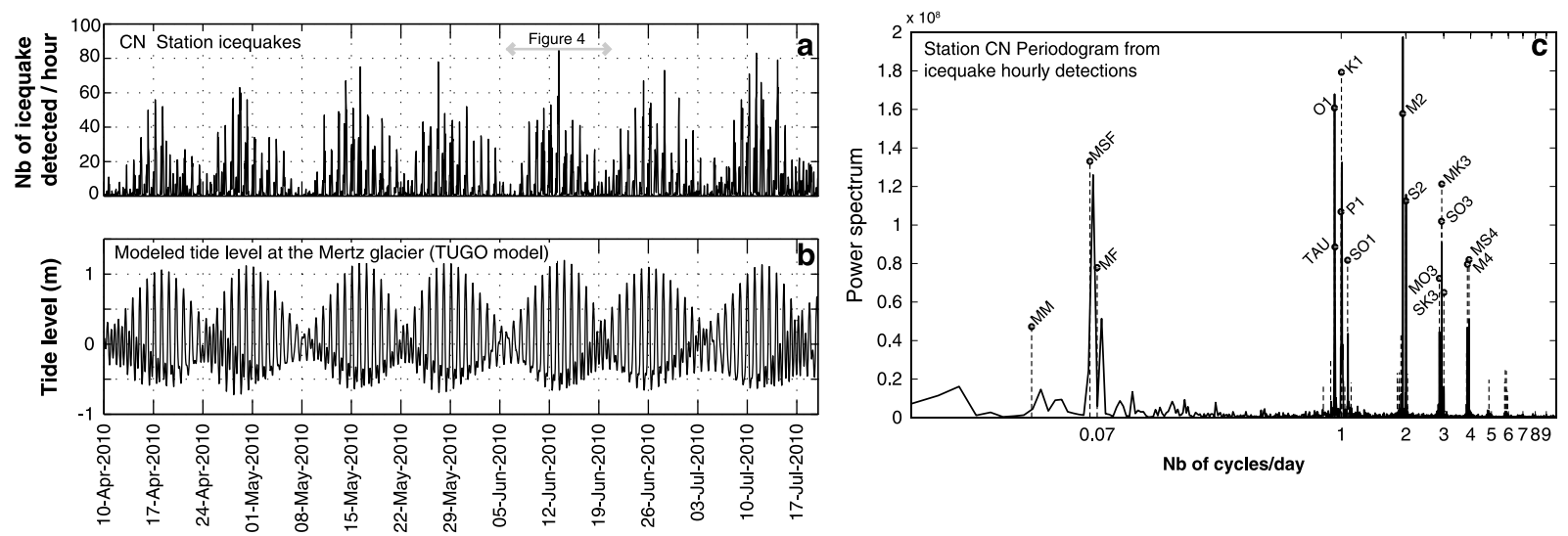

Figure 3. (a) Number of hourly detected icequakes at station CN during the period from 10 April 2010 to 20 July 2010. (b) Tide height output from the TUGO model at a point of latitude $-67.6^{\circ}$ and of longitude $144.4^{\circ}$ (at about $5 \mathrm{~km}$ from station CN in the middle of the Mertz glacier) for the same time period. (c) Power spectrum of the icequake activity at station $\mathrm{CN}$ issued from 10 months of continuous data. The vertical dashed lines indicate the main tidal frequencies (MM: monthly; MSF and MF: fortnightly; K1, P1, O1: diurnal; M2, S2: semidiurnal) calculated from the T-Tide software [Pawlowicz et al., 2002].

1944] with small icequakes more numerous than long-duration events. We found that the number $N$ of events of a given duration is linked to the duration magnitude $M_{d}$ through the relation $\log N=3.12-0.86 M_{d}$, with a linear trend and a correlation coefficient of $R=-0.94$. Such distribution of apparent magnitude suggests that the detected icequakes originate from faults or crack ruptures at short distance to the station.

\subsection{Icequake Occurrences, Sea Level Height, and Tide Velocity}

[9] The hourly occurrence of detected icequakes shows large variations from 0 to 100 events/h that may occur within a few hours. A time series of icequake activity recorded at $\mathrm{CN}$ between April and July 2010 is presented in Figure 3a, together with the sea level variation calculated from the Toulouse Unstructured Grid Ocean (TUGO) tide model [Lescarmontier et al., 2012; Mayet et al., 2013] (Figure 3b). This barotropic model uses the model FES2004 [Lyard et al., 2006] as boundary conditions and takes into account accurate coastlines, shallow water bathymetry, geometry, and thickness of the floating ice, together with the pressure and wind atmospheric forcing, to calculate the local tide and the induced local water circulation.

[10] We observe daily and fortnightly modulation of the microseismicity at this station, confirmed by the periodogram calculated from 10 months of continuous data (Figure $3 \mathrm{c}$ ). The power spectrum of hourly detected icequakes exhibits clear peaks close to the dominant tide periods such as the semidiurnal ( 2 cycles/d), diurnal (1 cycle/d), and fortnightly (0.07 cycles/d) variations. One also sees higher frequencies at 3 and 4 times/d that may correspond to complex local tide-bathymetry interaction [e.g., Murray et al., 2007].

[11] The harmonic analysis of the icequake activity using the T-Tide software package [Pawlowicz et al., 2002] confirms the clear tidal modulation of the icequake frequency by the fortnightly (MSF and MF), diurnal (K1, P1, O1), and semidiurnal (M2, S2) tide components. Among the 58 tide frequencies analyzed, these eight components explain about $40 \%$ of the total number of icequakes observed at station $\mathrm{CN}$, but if one considers the significant tidal constituents with a signal-to-noise ratio larger than 2.0, one retrieves 37 tide frequencies that explain about $90 \%$ of the icequake seismicity, demonstrating the major role of the tide on the local cryoseismicity.

[12] The comparison of icequake occurrences at station $\mathrm{CN}$ and the sea level height deduced from the TUGO tide model calculated on a point located on the Mertz glacier at $5 \mathrm{~km}$ east from $\mathrm{CN}$ shows a first icequake activity peak of small amplitude at midrising tide and a second peak of larger amplitude at midfalling tide. These midtide peaks correspond to the maximum of sea level velocity variation. The analysis of

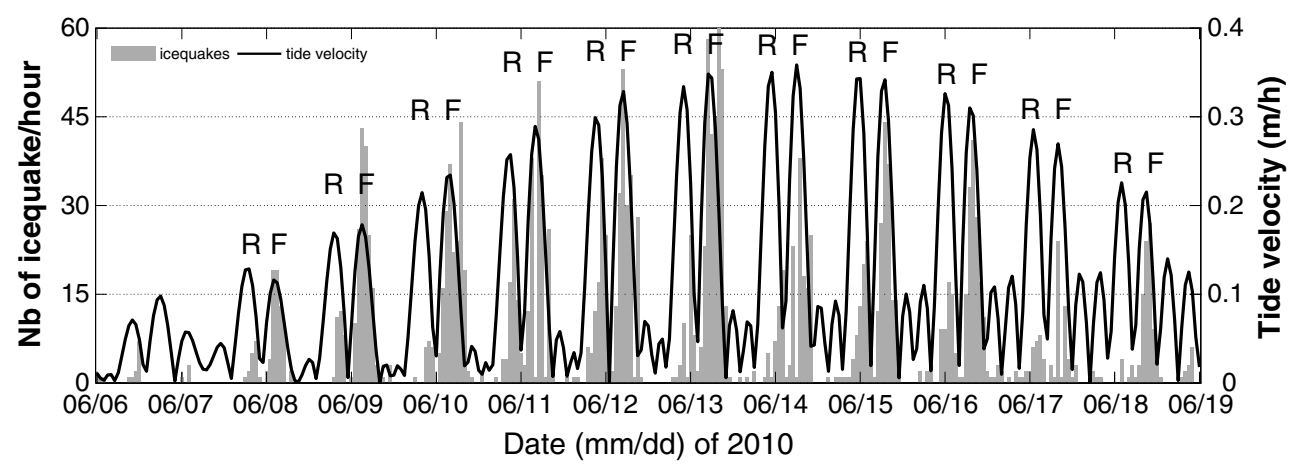

Figure 4. Example of variation of the hourly detected icequakes at station $\mathrm{CN}$ (grey bars) together with the predicted tide velocity amplitude (black line) for the 2 week period from 6 to 19 June 2010. R and F indicate rising and falling tides, respectively. 
icequake hourly frequency at station CN (Figure 4), together with the tide vertical velocities issued from the TUGO model (rising and falling tides are indicated by $\mathrm{R}$ and $\mathrm{F}$, respectively), reveals the following features.

[13] 1. No icequakes are detected at low tide velocity, i.e., close to high and low stages.

[14] 2. Icequakes are detected above a tide velocity threshold of about $0.1 \mathrm{~m} / \mathrm{h}$.

[15] 3. On a diurnal cycle, the icequake activity is lower during rising $(\mathrm{R})$ than falling $(\mathrm{F})$ tides, and the maximum peak occurs during falling tides close to the maximum tide velocity.

[16] 4. On a 2 week cycle, the maximum number of icequakes coincides with spring tides, whereas neap tides do not generate any significant number of icequakes.

\section{Discussion and Conclusion}

[17] The extremely small event magnitudes and the station spacing impede to locate the detected icequakes. The difficulty in retrieving events recorded simultaneously by several stations was already described in several glacier experiments using a station spacing of 2-3 km [Smith, 2006; West et al., 2010], but icequakes were successfully located by using short-scale seismic deployments $(<1 \mathrm{~km})$ [e.g., Bassis et al., 2007]. This suggests that icequakes can be detected within the few kilometers around the station. Such a very local source of seismicity is consistent with the surface crevassing of the Mertz glacier starting southeast of the $\mathrm{CN}$ station (Figure 1c) and with the nearby presence of the grounding line (Figure 1b). We propose three different (and nonexclusive) origins (Figure S5 in the supporting information) to explain the observed seismicity.

[18] 1. Friction of the glacier on the outcropping basement (Figure S5a in the supporting information). The vertical up and down tide-induced motions of the floating Mertz glacier, with a typical amplitude of $1 \mathrm{~m}$, may generate local ice fracturing and seismicity in contact with the Correll Nunatak. Such friction is expected to be larger at falling tides, during the resettlement of the glacier on the nunatak, than at rising tides, which is consistent with our observations. In this hypothesis, the periods with no icequake suggest that the continuous Mertz flow is either undisturbed by bedrock topography in the vicinity of the nunatak or may generate microseismic events too small to be detected.

[19] 2. Brittle deformation of the glacier generated by its flexure during falling tides (Figure S5b in the supporting information). The relative vertical motion between the grounded and floating ice tongues is expected to bend the glacier [e.g., Vaughan, 1995], generating an extensive state of stress in the upper part of the glacier along the grounding line and inducing mode I microfracturing at the glacier outer curve. This may explain the icequake occurrences during the tide descending phase and the maximum number of icequakes corresponding to the maximum velocity of the sea level variation.

[20] 3. Brittle deformation of the glacier induced by its flexure during rising tides (Figure S5c in the supporting information). If the glacier is mechanically coupled to the fjord walls on its lateral sides, one expects a flexure of the ice slab along the lateral boundaries during the rising tides, as evidenced by geodetic measurements in Greenland [Reeh et al., 2003] and mode I ice surface fracturing along the zone of maximum flexure, expected to be at $2-5 \mathrm{~km}$ from the fjord walls [Reeh et al., 2003; Walker et al., 2013]. Such a lateral boundary, parallel to the $\mathrm{N} 30^{\circ} \mathrm{E}$ Mertz flow direction, is present south and northwest of $\mathrm{CN}$, as observed by GPS and InSAR [Legresy et al., 2004] (Figure 1b). The smaller amplitude of these peaks (Figure 4) may reflect the larger distance between $\mathrm{CN}$ and the lateral boundary of the Mertz glacier.

[21] In the flexure models, the glacier behaves differently during phases of bending and unbending: flexure gives rise to stretching brittle deformation on its outer curve above the ice brittle-ductile transition [Schulson et al., 1984] and likely to a plastic and, therefore, seismically silent compressive deformation below. After the flexure, while the glacier recovers its initial position, unbending is expected to close and heal the surface microfractures, which is an aseismic process, and to induce a tensile deformation at the bottom of the glacier. The absence of detected event during this phase can be explained either by the larger distance to the station or by ductile and aseismic deformation. This may explain why only the bending phases may generate icequakes, whereas the unbending phases remain seismically quiet.

[22] The threshold of about $0.1 \mathrm{~m} \mathrm{~h}^{-1}$ in the vertical sea level velocity below which no icequake is detected may have several explanations: (i) Brittle deformation may occur above a strain rate threshold, which is consistent with laboratory experiments indicating that icequake generation, i.e., brittle deformation, requires large strain rates [Schulson et al., 1984]. (ii) Subcritical, slow, and silent deformation may follow mode I crack opening [Weiss, 2004]. (iii) Non-tide-induced events may originate too far from the nunatak to be detected.

[23] Continuous icequake detection performed in the grounding area of the Mertz glacier reveals that local deformation processes are closely related to tide vertical velocity. The glacier flexure and its friction on the bedrock are proposed to be the dominant mechanisms that generate icequakes in the few kilometers around Correll Nunatak. The bending is likely to be active at both rising and falling tides by increasing the tensile state of stress at the surface of the glacier: first, in the grounding area during falling tides and, second, along the lateral boundary of the glacier at rising tides. The complex shape of the grounding line around Correll Nunatak may explain the simultaneous presence of along- and across-flow bending occurring at falling and rising tides, respectively. The tide-induced microseismicity at the Mertz glacier grounding line is also observed, but at a lower degree, at stations DRV and PP, both located at less than $10 \mathrm{~km}$ from floating ice tongues, suggesting that the seismic observations of the kind performed at the Mertz grounding line may be made at other sites and may provide insights on the mechanical stability of ice shelves in regard of sea level rise.

[24] Acknowledgments. This work was supported by the French polar institute (IPEV, Institut Polaire Paul Emile Victor). Portable seismometers were provided by the French national pool of portable seismic instruments SisMob-RESIF of the CNRS-INSU. Thanks are due to the GEOSCOPE network for the availability and the high-quality data and to V. Tsai for fruitful discussions. The tidal predictions and satellite images were prepared through the CRACICE project.

[25] The Editor thanks Anya M. Reading and an anonymous reviewer for their assistance in evaluating this paper.

\section{References}

Anandakrishnan, S., and R. B. Alley (1997), Tidal forcing of basal seismicity of ice stream C, West Antarctica, observed far inland, J. Geophys. Res., 102(B7), 15,183-15,196, doi:10.1029/97jb01073. 


\section{BARRUOL ET AL.: MERTZ GLACIER TIDE-MODULATED ICEQUAKES}

Bassis, J. N., H. A. Fricker, R. Coleman, Y. Bock, J. Behrens, D. Darnell, M. Okal, and J. B. Minster (2007), Seismicity and deformation associated with ice-shelf rift propagation, J. Glaciol., 53, 523-536, doi:10.3189/ 002214307784409207.

Bindschadler, R. A., M. A. King, R. B. Alley, S. Anandakrishan, and L. Padman (2003), Tidally controlled stick-slip discharge of a West Antarctic Ice Stream, Science, 301, 1087-1089.

Gutenberg, B., and C. F. Richter (1944), Frequency of earthquakes in California, Bull. Geol. Soc. Am., 34, 185-188.

Lee, W. H. K., R. E. Bennett, and K. L. Meagher (1972), A method of estimating magnitude of local earthquakes from signal duration, U.S. Geol. Surv. Open File Rep., 1-29.

Legresy, B., A. Wendt, I. Tabacco, F. Remy, and R. Dietrich (2004), Influence of tides and tidal current on Mertz glacier, Antarctica, J. Glaciol., 50(170), 427-435, doi:10.3189/172756504781829828.

Lesage, P. (2009), Interactive Matlab software for the analysis of seismic volcanic signals, Comput. Geosci., 35(10), 2137-2144, doi:10.1016/j. cageo.2009.01.010.

Lescarmontier, L. (2012), Etude des processus de fracturation, de déformation et de vêlage d'iceberg en Antarctique: Une histoire du glacier Mertz, Doctorat thesis, 248 pp., Toulouse.

Lescarmontier, L., B. Legresy, R. Coleman, F. Perosanz, C. Mayet, and L. Testut (2012), Vibrations of Mertz glacier ice tongue, East Antarctica, J. Glaciol., 58(210), 665-676, doi:10.3189/2012JoG11J089.

Lyard, F., F. Lefevre, T. Letellier, and O. Francis (2006), Modelling the global ocean tides: Modern insights from FES2004, Ocean Dyn., 56(5-6), 394-415, doi:10.1007/s10236-006-0086-x.

Mayet, C., L. Testut, B. Legresy, L. Lescarmontier, and F. Lyard (2013), High resolution barotropic modeling and the calving of the Mertz glacier, East Antarctica, J. Geophys. Res. Oceans, doi:10.1002/jgrc.20339, in press.

Murray, T., A. M. Smith, M. A. King, and G. P. Weedon (2007), Ice flow modulated by tides at up to annual periods at Rutford Ice Stream, West Antarctica, Geophys. Res. Lett., 34, L18503, doi:10.1029/2007g1031207.

Neave, K. G., and J. C. Savage (1970), Icequakes on Athabasca glacier, J. Geophys. Res., 75(8), 1351-1362, doi:10.1029/JB075i008p01351.

O'Neel, S., H. P. Marshall, D. E. McNamara, and W. T. Pfeffer (2007), Seismic detection and analysis of icequakes at Columbia Glacier, Alaska, J. Geophys. Res., 112, F03S23, doi:10.1029/2006jf000595. von der Osten-Woldenburg, H. (1990), Icequakes from Ekström ice shelf near Atka Bay, Antarctica, J. Glaciol., 36(122), 31-36.

Pawlowicz, R., B. Beardsley, and S. Lentz (2002), Classical tidal harmonic analysis including error estimates in MATLAB using T-TIDE, Comput Geosci., 28(8), 929-937, doi:10.1016/s0098-3004(02)00013-4.

Reeh, N., E. L. Christensen, C. Mayer, and O. B. Olesen (2003), Tidal bending of glaciers: A linear viscoelastic approach, Ann. Glaciol., 37, 83-89, doi:10.3189/172756403781815663.

Schulson, E. M., P. N. Lim, and R. W. Lee (1984), A brittle to ductile transition in ice under tension, Philos. Mag., 49(3), 353-363.

Sinadinovski, C., K. Muirhead, M. Leonard, S. Spiliopoulos, and D. Jespen (1999), Effective discrimination of icequakes on seismic records from Mawson station, Phys. Earth Planet. Inter., 113(1-4), 203-211, doi:10.1016/ s0031-9201(99)00005-9.

Smith, A. M. (2006), Microearthquakes and subglacial conditions, Geophys. Res. Lett., 33, L24501, doi:10.1029/2006g1028207.

Talandier, J., O. Hyvernaud, D. Reymond, and E. Okal (2006), Hydroacoustic signals generated by parked drifting icebergs in the Southern Indian and Pacific Ocean, Geophys. J. Int., 246, 1-18, doi:10.1111/j.1365246X.2006.02911.x.

Tsai, V. C., and G. Ekstrom (2007), Analysis of glacial earthquakes, J. Geophys. Res., 112, F03s22, doi:10.1029/2006jf000596.

Vaughan, D. G. (1995), Tidal flexure at ice shelf margins, J. Geophys. Res., 100(B4), 6213-6224.

Walker, R. T., B. R. Parizek, R. B. Alley, S. Anandakrishnan, K. L. Riverman, and K. Christianson (2013), Ice-shelf tidal flexure and subglacial pressure variations, Earth Planet. Sci. Lett., 361, 422-428, doi:10.1016/j. eps1.2012.11.008.

Weiss, J. (2004), Subcritical crack propagation as a mechanism of crevasse formation and iceberg calving, J. Glaciol., 50(168), 109-115, doi: $10.3189 / 172756504781830240$

Wendler, G., K. Ahlnas, and C. S. Lingle (1996), On Mertz and Ninnis glaciers, East Antarctica, J. Glaciol., 42(142), 447-453.

West, M. E., C. F. Larsen, M. Truffer, S. O’Neel, and L. LeBlanc (2010), Glacier microseismicity, Geology, 38(4), 319-322, doi:10.1130/g30606.1.

Zoet, L. K., S. Anandakrishnan, R. B. Alley, A. A. Nyblade, and D. A. Wien (2012), Motion of an Antarctic glacier by repeated tidally modulated earthquakes, Nat. Geosci., 5(9), 623-626, doi:10.1038/ngeo1555. 